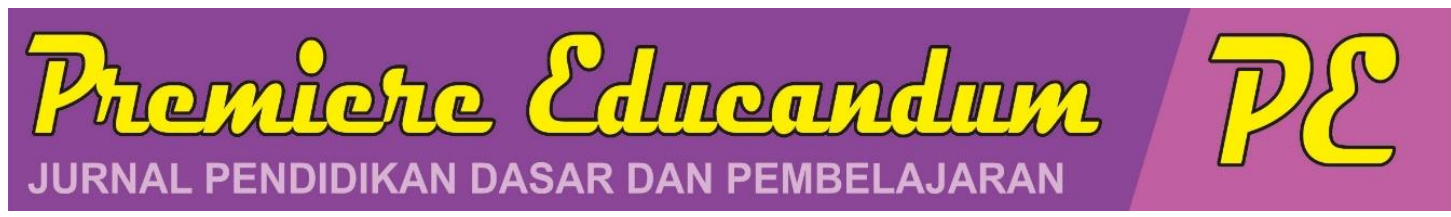

Premiere Educandum: Jurnal Pendidikan Dasar dan Pembelajaran

Volume 9 (2) 141 - 159 Desember 2019

Copyright @2019 Universitas PGRI Madiun

ISSN: 2088-5350 (Print) / ISSN: 2528-5173 (Online)

Available at: http://e-journal.unipma.ac.id/index.php/PE

Doi: 10.25273 /pe.v9i2.4987

\title{
Nidzomul Ma'had dalam pendidikan akhlak di Pesantren Cipari Kabupaten Garut
}

\author{
Nuraly Masum Aprily ${ }^{1}$ \\ ${ }^{1}$ Sekolah Pascasarjana, Universitas Pendidikan Indonesia \\ 1email: nuralymasumaprily@upi.edu
}

\begin{abstract}
The application of moral education in pesantren which is full of noble values has succeeded in forming its students to have a good school culture and character, through various methods and models typical of the pesantren itself. Related to general schools in this case special education institutions for basic education (primary education) can adapt some important things from the model of moral education in pesantren. The purpose of this study is to describe how moral education in the Cipari boarding school through the Nidzomul Ma'had program and its implementation process. This research uses qualitative methods with case study research methods. Data collected through observation, interviews, documentation studies, and literature studies. Data analysis techniques by data reduction, data presentation, conclusion and verification. The results of this study are 1) the Nidzomul Ma'had Implementation Program for Cipari boarding students; 2) The process of conducting moral education in Cipari boarding schools through four stages which include: uswatun hasanah (exemplary); practice and habituation; practice; and the study of the yellow book and mauidzhotul hasanah (good advice).
\end{abstract}

Keywords: Akhlaq Education, Character Education, Boarding School, Primary Education

\begin{abstract}
Abstrak
Penerapan pendidikan akhlak di pesantren yang sarat akan nilai-nilai mulia telah berhasil membentuk santri-santrinya memiliki budaya sekolah dan karakter yang baik, melalui berbagai metode dan model khas pesantren itu sendiri. Sehingga sekolah-sekolah umum dalam hal ini lembaga pendidikan khususnya pendidikan dasar (SD) dapat mengadaptasi beberapa hal penting dari model pendidikan akhlak di pesantren. Tujuan penelitian ini adalah mendeskripsikan bagaimana pendidikan akhlak di pesantren Cipari melalui program Nidzomul Ma'had dan proses penyelenggaraannya. Penelitian ini menggunakan pendekatan kualitatif dengan metode penelitian studi kasus. Data dikumpulkan melalui observasi, wawancara, studi dokumentasi, dan studi literatur. Teknik analisis data dengan cara reduksi data, penyajian data, penarikan kesimpulan dan verifikasi. Hasil penelitian ini adalah 1) Penerapan program Nidzomul Ma'had kepada para santri pesantren Cipari; 2) Proses penyelenggaraan pendidikan akhlak di pesantren Cipari melalui empat tahapan yang meliputi: uswatun hasanah (keteladanan); latihan dan pembiasaan; pengamalan; serta pengajian kitab kuning dan mauidzhotul hasanah (nasihat yang baik).
\end{abstract}

Kata Kunci: Pendidikan Akhlak, Pendidikan Karakter, Pondok Pesantren, Santri, Sekolah Dasar

Histori artikel : disubmit pada 22 Agustus 2019; direvisi pada 27 September 2019; diterima pada 31

Oktober 2019 


\section{A. PENDAHULUAN}

Pelaksaanaan

program pendidikan karakter di lembaga pendidikan di Indonesia sudah berlangsung sekitar 9 tahun lamanya sejak dicanangkan pada tahun 2010 , namun diakui atau tidak pada implementasi dapat dikatakan belum berhasil, karena masalah-masalah immoralitas pada diri pelajar justru semakin bervariasi. Memang harus dipahami, bahwa pendidikan karakter hanyalah sebagai salah satu ikhtiar dan usaha pemerintah untuk memperbaiki kualitas karakter manusia Indonesia, oleh karena itu tentu perlu adanya perbaikan secara terus menerus dalam pelaksanaan pendidikan karakter di sekolah dan lembaga pendidikan.

Penyebab belum berhasilnya pendidikan karakter di sekolah dewasa ini bukan disebabkan kurangnya nilai-nilai karakter yang ditawarkan atau ditetapkan oleh pemerintah atau sekolah, akan tetapi proses menyampaikan dan mentransfer karakter itulah yang masih perlu diperbaiki dan ditingkatkan. Sebagai contoh metode pembelajarannya masih lemah karena terlalu fokus pada aspek kognitif level rendah seperti recall misalnya, namun belum merangsang aspek cognitive moral development di mana guru hanya mewajibkan peserta didik untuk mengetahui, menghafal konsep dan kebenaran tanpa menyentuh perasaan dan hati nurani yang merupakan orientasi dari cognitive moral development. Hanafi (2017, hlm 37) dalam penelitiannya menjelaskan bahwa rancangan pendidikan karakter sekarang ini membuat guru tidak fokus dalam menyentuh pribadi peserta didik sehingga nilai-nilai karakter tidak sepenuhnya tertanam menjadi watak dan kepribadian dari peserta didik, sehingga nilai-nilai karakter hanya sekadar hafalan saja. Pendidikan karakter apabila ditinjau dari perspektif psikologis dan filosofis memerlukan suatu strategi pedagogi dan metodologi yang tepat untuk menanamkan nilai-nilai kebaikan kepada diri peserta didik melalui pembelajaran di sekolah atau lembaga pendidikan lainnya (Cooley, 2008), karena ketidaktepatan metode yang digunakan menyebabkan pendidikan karakter menjadi tidak efektif. Kesalahan metodologis dan strategi pedagogis dalam praktik pendidikan karakter di sekolah akan berdampak panjang pada kehidupan moral siswa.

Berangkat dari keprihatinan dan fenomena belum berhasilnya penerapan pendidikan karakter di sekolah-sekolah umum oleh mantan Menteri Pendidikan Nasional, Muhammad Nuh ditanggapi dengan serius. Beliau akan mencontoh menerapkan model pendidikan karakter yang ada di pesantren dengan diberlakukan pada sekolah umum. Karena model pendidikan karakter yang dikembangkan oleh pesantren menurut beliau telah berhasil (N. Hidayat, 2016). Tujuan transfer pendidikan karakter dari pesantren adalah untuk membentuk budaya sekolah yang dilakukan melalui pembiasaan nilai-nilai positif yang ada di sekolah. Ada beberapa hal penting yang bisa ditransfer dari sistem model pesantren ke lembaga pendidikan umum, seperti keteladanan, 
pembiasaan, kepribadian, kepemimpinan, dan kewibawaan (K. Hidayat, 2008).

Nofiaturrahmah (2017) dalam penelitiannya menyatakan bahwa pesantren telah terbukti secara empiris mampu mengembangkan santri dari berbagai aspek, meliputi kemampuan intelektual, emosional dan pembentukan watak religius, sehingga lahirlah output pesantren yang memiliki pengetahuan dan akhlakul karimah atau berkarakter.

Selain itu dalam penelitian yang dilakukan oleh Yahya (2016), diperoleh hasil mengenai implikasi model pendidikan karakter yang dilakukan di pesantren yaitu, peningkatan kepribadian santri menjadi lebih baik melalui pembinaan yang dilakukan oleh pesantren berupa penegakan disiplin, membiasakan santri mengikuti semua kegiatan di dalam pesantren, serta peran Kyai dan Ustadz dalam memberikan keteladanan bagi para santrinya.

Sementara itu dalam penelitian yang dilakukan oleh Sumardi (2012) diperoleh hasil bahwa selain faktor keteladanan dan contoh nyata dalam kehidupan sehari yang diberikan oleh Kyai dan para Ustadz dalam mendidik karakter santrinya, ditemukan bahwa pendidikan karakter tidak harus selalu menggunakan kurikulum yang formal, tetapi cukup dengan hidden curriculum di mana pendidikan karakter tidak cukup hanya dilakukan di dalam kelas, melainkan harus dilakukan secara simultan di dalam dan di luar kelas. Ditemukan juga bahwa pendidikan karakter yang dilakukan di pesantren bukan merupakan bentuk "paksaan" namun dijalani sebagaimana adanya kehidupan keseharian santri melalui berbagai macam kegiatan dalam pesantren yang justru akan membuat nilai-nilai karakter baik yang ditanamkan akan melekat dengan sendirinya pada diri setiap santri karena nilai-nilai itu sudah menjadi sebuah budaya di pesantren.

\section{B. METODE PENELITIAN}

Penelitian ini adalah jenis penelitian lapangan dengan pendekatan kualitatif. Kirk dan Miller mendefinisikan penelitian kualitatif sebagai tradisi khusus dalam ilmu sosial yang secara fundamental tergantung pada pengamatan manusia baik dalam wawasan maupun dalam terminologi (Moleong, 2009, hlm. 6).

Pendekatan kualitatif yang digunakan dalam penelitian ini adalah untuk mengetahui dan mendeskripsikan secara jelas dan rinci tentang program Nidzomul Ma'had dan proses pelaksanaan pendidikan akhlak di pesantren Cipari, oleh karena itu peneliti melakukan serangkaian kegiatan di lapangan mulai dari eksplorasi hingga lokasi penelitian, studi orientasi, dan dilanjutkan dengan studi terfokus di pondok pesantren Cipari.

Penelitian ini menggunakan desain penelitian studi kasus. Dalam prosesnya, langkah-langkah yang akan dilakukan oleh peneliti adalah mengamati bagaimana proses pelaksanaan pendidikan akhlak yang dilakukan oleh pesantren, kegiatan sehari-hari para santri yang terdapat dalam program Nidzomul Ma'had 
pondok pesantren Cipari, untuk mendukung persyaratan data peneliti akan mewawancarai 1 orang Kyai / pimpinan lembaga, 2 ustadz, dan 1 santri di pondok pesantren Cipari yang akan memberikan akses dan informasi pendukung untuk mendukung penelitian ini. Staf pengajar / ulama, ulama, dan santri diwawancarai untuk memberikan pandangan dan pengalaman mereka tentang pendidikan karakter di Pondok Pesantren Cipari.

Guna menjaring dan mengumpulkan data penelitian yang dibutuhkan serta pedoman/instrumen data yang digunakan yang melibatkan sumber-sumber data dalam penelitian ini, secara lebih rinci dapat dilihat pada tabel di bawah ini:

Tabel 1 Indikator dan Penjaringan Data

\begin{tabular}{|c|c|c|}
\hline $\begin{array}{l}\text { Masalah } \\
\text { Penelitian }\end{array}$ & $\begin{array}{l}\text { Sumber } \\
\text { Data/Informasi }\end{array}$ & $\begin{array}{l}\text { Bentuk } \\
\text { Pedoman/Instr } \\
\text { umen }\end{array}$ \\
\hline $\begin{array}{l}\text { Bagaimana } \\
\text { kah } \\
\text { penerapan } \\
\text { program } \\
\text { Nidzomul } \\
\text { Ma'had di } \\
\text { pesantren } \\
\text { Cipari? }\end{array}$ & $\begin{array}{l}\text {-Seorang Kyai } \\
\text { (pimpinan } \\
\text { pesantren) } \\
\text {-Dua orang } \\
\text { ustadz. } \\
\text {-3 orang santri } \\
\text { pesantren } \\
\text { Cipari . } \\
\text {-Dokumentasi } \\
\text { Nidzomul } \\
\text { ma'had (tata } \\
\text { tertib } \\
\text { pesantren). } \\
\text {-Pemberian } \\
\text { reward } \\
\text { (penghargaan) } \\
\text { kepada santri } \\
\text { yang } \\
\text { berprestasi. } \\
\text {-Dokumentasi } \\
\text { Jadwal } \\
\text { kegiatan } \\
\text { harian, } \\
\text { mingguan, } \\
\text { bulanan, dan } \\
\text { tahunan di }\end{array}$ & $\begin{array}{l}\text {-Pedoman } \\
\text { Wawancara. } \\
\text { - Pedoman } \\
\text { studi } \\
\text { dokumentas } \\
\text { i berupa } \\
\text { dokumen } \\
\text { Nidzomul } \\
\text { ma'had (tata } \\
\text { tertib } \\
\text { pesantren). } \\
\text { - Dengan alat } \\
\text { bantu } \\
\text { berupa: } \\
\text { - Alat } \\
\text { perekam } \\
\text { suara } \\
\text { - Kamera } \\
\text { photo } \\
\text { (handphone) } \\
\text { - Catatan } \\
\text { lapangan }\end{array}$ \\
\hline
\end{tabular}

\begin{tabular}{|c|c|c|}
\hline & $\begin{array}{l}\text { pesantren } \\
\text { Cipari. } \\
\text { - Alat evaluasi } \\
\text { pendidikan } \\
\text { karakter di } \\
\text { pesantren } \\
\text { Cipari. }\end{array}$ & \\
\hline $\begin{array}{l}\text { Bagaimana } \\
\text { kah } \\
\text { penyelenga } \\
\text { raan } \\
\text { pendidikan } \\
\text { akhlakq di } \\
\text { pondok } \\
\text { Pesantren } \\
\text { Cipari? }\end{array}$ & 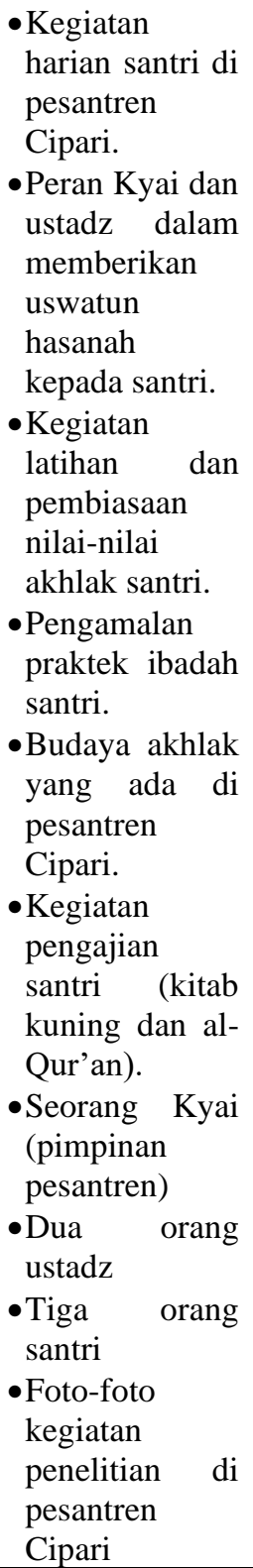 & $\begin{array}{l}\text {-Pedoman } \\
\text { Observasi. } \\
\text {-Pedoman } \\
\text { studi } \\
\text { dokumentas } \\
\text { i. } \\
\text { - Pedoman } \\
\text { wawancara. } \\
\text { - Dengan alat } \\
\text { bantu } \\
\text { berupa: } \\
\text { - Kamera } \\
\text { photo } \\
\text { (handphone) } \\
\text { - } \\
\text {-Catatan } \\
\text { lapangan. } \\
\text { - Alat } \\
\text { perekam. }\end{array}$ \\
\hline
\end{tabular}

Teknik triangulasi sumber data yang dimaksudkan dalam penelitian ini agar dalam pengumpulan data peneliti menggunakan multi sumber data, yakni dengan menggunakan sumber data dalam bentuk informasi yang didapatkan melalui wawancara dengan Kyai, para Ustadz, dan juga 
santri di pesantren Cipari, peristiwaperistiwa yang terjadi di pesantren Cipari yang didapatkan melalui observasi terhadap kegiatan-kegiatan yang dilakukan santri, latihan dan pembiasaan nilai-nilai akhlak, serta perilaku Kyai dan para ustadz dalam memberikan keteladanan bagi para santrinya sebagai upaya mendidik dan membina akhlak santri pesantren Cipari, dan informasi melalui dokumen dokumen-dokumen pendukung lainnya.

Analisis data dilakukan dalam beberapa tahap, yaitu: mengorganisasikan data, mendeskripsikannya ke dalam unit, mensintesis, menyusun ke dalam pola, dan membuat kesimpulan yang dapat diceritakan kepada orang lain. Karena mengolah dan menganalisis data adalah upaya untuk mengatur data secara sistematis.

\section{HASIL DAN PEMBAHASAN}

Dalam penelitian ini, penelitian mendapatkan hasil yang akan dibahas dalam dua poin utama yaitu:

1) Program Nidzomul Ma'had di Pesantren Cipari

2) Penyelenggaraan Pendidikan Karakter di Pesantren Cipari

Tabel 2 Temuan Penelitian

\begin{tabular}{|c|c|c|}
\hline & $\begin{array}{l}\text { Temuan } \\
\text { Penelitian }\end{array}$ & Uraian \\
\hline \multirow[t]{2}{*}{$\begin{array}{l}\text { Pendidik } \\
\text { an } \\
\text { Akhlak } \\
\text { di } \\
\text { Pesantre } \\
\text { n Cipari }\end{array}$} & $\begin{array}{l}\text { Program } \\
\text { Nidzomul } \\
\text { Ma'had } \\
\text { Pesantren } \\
\text { Cipari }\end{array}$ & $\begin{array}{l}\text { - Jadwal kegiatan } \\
\text { harian santri } \\
\text { - Kegiatan } \\
\text { Pembiasaan } \\
\text { - Aturan dan } \\
\text { sangsi-sangsi } \\
\text { bagi santri yang } \\
\text { melanggar }\end{array}$ \\
\hline & $\begin{array}{l}\text { Proses } \\
\text { Penyelenggar } \\
\text { aan }\end{array}$ & $\begin{array}{l}\text {-Uswatun } \\
\text { Hasanah } \\
\text { (Keteladan) }\end{array}$ \\
\hline
\end{tabular}

\begin{tabular}{lll}
\hline Pendidikan & • Latihan dan \\
Akhlk di & Pembiasaan \\
Pesantren & & • Pengamalan \\
Cipari & & - Pengajian Kitab \\
& Kuning dan \\
& Mauidzotul \\
& Hasanah \\
& (nasehat yang \\
& baik) \\
\hline
\end{tabular}

\section{1) Program Nidzomul Ma'had Pesantren Cipari}

$$
\text { Pesantren Cipari memiliki }
$$
Nidzomul Ma'had (tata tertib pesantren) sebagai salah satu program unggulan dalam mendidik karakter dan akhlak para santrinya, di mana di dalamnya berisi tentang aturan-aturan berupa hak dan kewajiban santri, jadwal kegiatan harian, mingguan, bulanan, dan tahunan yang harus diikuti oleh seluruh santri, hak dan kewajiban orang tua wali santri, jenisjenis larangan beserta sangsinya, tata tertib asrama, tata tertib makan hingga kegiatan olahraga dan kesenian yang dapat diikuti oleh santri. Adanya Nidzomul Ma'had terbukti cukup efektif dalam mendidik akhlak para santri, selain untuk membatasi perilaku santri dari perilaku-perilaku yang menyimpang, juga sebagai sarana melatih, membiasakan, dan mempraktekkan nilai-nilai kebaikan dalam kehidupan para santri.

Selain itu untuk menunjang dan memperkuat aturan-aturan yang berlaku, pesantren Cipari juga memiliki jenis-jenis ta'zir (sangsi) bagi santri yang melanggar peraturan, hal tersebut merupakan salah kewajiban pesantren dalam hal ini Kyai dan para ustadz untuk mengingatkan dan menegur anak 
didiknya apabila berbuat kesalahan, dengan cara meluruskan kesalahan tersebut dengan nasihat yang baik.

Selain memberikan ta'zir dan hukuman bagi santri yang melanggar peraturan dan tata tertib yang berlaku di pesantren sebagai bagian dari program dalam mendidik akhlak para santrinya, pesantren Cipari juga akan memberikan reward (penghargaan) kepada santrinya yang berprestasi dan berkelakuan baik, pemberian beasiswa kepada santri yang berprestasi merupakan salah satu usaha untuk memberikan motivasi kepada santri yang lain untuk meraih prestasi yang sama bahkan melebihi pencapaian temannya. Hal tersebut sesuai dengan pendapat Pradjarta (1994, hlm. 17) jika seorang pendidik menemukan penyimpangan yang terjadi pada anak didik, maka dalam perspektif Ibnu Sina seorang pendidik harus meluruskan, memperbaiki penyimpangan tersebut dengan cara menunjukkan kesalahan anak didik tersebut dengan pengarahan, ramah tamah atau harus dengan hukuman yang menyenangkan baginya. Artinya hukuman yang penuh kasih sayang karena naluri manusia selalu ingin disayang. Hukuman diambil sebagai hasil akhir apabila teguran, peringatan belum mampu mencegah anak untuk melakukan pelanggaran. Selain memberikan hukuman guru juga diharuskan memberikan hadiah atau penghargaan kepada pelajar yang berkelakuan baik atau yang berprestasi. Pemberian hadiah bertujuan untuk memotivasi pelajar yang lain sekaligus sebagai bentuk apresiasi atas pencapaian yang telah diraih oleh peserta didik.

Nidzomul Ma'had dirasakan
sangat efektif sebagai program
pendidikan akhlak di pesantren Cipari, karena di dalamnya mencakup semua hal yaitu, peraturan, tata tertib, larangan-larangan, sangsi dan jenis hukuman yang dalam terminologi pesantren Cipari disebut dengan ta'zir bagi santri yang melanggar. Saat para santri sedang tidak berada di lingkungan pondok atau sedang berlibur di rumah, Nidzomul Ma'had juga memiliki peran untuk mengontrol dan mengawasi perilaku santri saat berada dirumah tentunya bekerjasama dengan orang tua, karena di dalam buku Nidzomul Ma'had (tata tertib pesantren) ada peraturan yang menyatakan bahwa selama santri sedang menempuh pendidikan di pesantren maka para santri harus tetap mengikuti semua aturan dan tata tertib pesantren baik sedang di dalam maupun di luar pesantren.

Berbicara mengenai program dan kurikulum pesantren terutama pada pesantren tradisional, istilah kurikulum tidak dapat ditemukan, walaupun materinya ada di dalam proses pengajaran, bimbingan rohani dan latihan kecakapan dalam kehidupan sehari-hari di pesantren (A. Steenbrink, 1994). Sejalan dengan pendapat di atas, Kafrawi (1978) menjelaskan bahwa yang dimaksud dengan kurikulum pesantren adalah seluruh aktivitas santri sehari semalam, yang kesemuanya itu dalam kehidupan pesantren memiliki nilainilai pendidikan. 
Kurikulum yang dikembangkan pesantren mengintegrasikan antara ilmu pengetahuan umum dengan materi keagamaan. Materi keagamaan mencakup materi aqidah, akhlak, Qur'an, hadits, dll. Sharma (dalam Rahmadi, 2014, hlm. 2) mengungkapkan suatu sistem pendidikan yang baik dan progresif seharusnya memasukkan isi (contents) yang berorientasi nilai (values) ke dalam kurikulumnya.

Rahmadi (2014) melanjutkan, bahwa merencanakan adalah kegiatan persiapan untuk tindakan-tindakan apa yang akan dilaksanakan. Langkah perencanaan menentukan apa yang seharusnya dikerjakan, oleh siapa, ke mana, kapan, dan bagaimana. Kyai sebagai pimpinan pesantren yang memegang kontrol penuh pelaksanaan pendidikan karakter telah menjalankan fungsinya sebagai manajer di mana memberikan arahan kepada para ustadz mengenai langkah-langkah apa yang harus dilakukan agar pembinaan akhlak dan karakter para santri dapat berjalan secara efektif.

Selain program Nidzomul Ma'had di pesantren juga didukung dengan sistem pendidikan 24 jam yang juga menjadi salah satu kekhasan yang membedakan pelaksanaan pendidikan karakter di lembaga pendidikan umum. Dalam menjalankan peran dan fungsinya sebagai lembaga pendidikan sekaligus lembaga keagamaan, pesantren menggunakan pendekatan holistis. Artinya, di pesantren semua kegiatan belajar mengajar dan aktivitas kehidupan, termasuk aktivitas keagamaan merupakan kesatu paduan utuh dalam totalitas kehidupan seharihari (Mastuhu, 1994)

Realita seperti ini mungkin bagi sebagian orang dianggap bukan sebagai sistem pendidikan ideal, tetapi itulah realitasnya. Pesantren dengan argumentasinya melihat bahwa dengan pendekatan seperti ini lebih efektif, dari pada pendekatan yang serba terukur, tetapi hasilnya nihil dan jauh dari yang diharapkan (Zamakhsari, 2011, hlm. 98).

Sekarang ini, ada dua fenomena menarik dalam dunia pendidikan di Indonesia yakni (a) munculnya sekolah-sekolah terpadu (mulai tingkat dasar hingga menengah); (b) penyelenggaraan sekolah bermutu yang sering disebut dengan boarding school (Syafe'i, 2017). Sisi positifnya adalah banyak sekolah yang mengadaptasi pola pendidikan pesantren, secara tidak langsung mengakui ternyata lulusan pesantren tidak kalah mutunya dengan lulusan sekolah-sekolah umum.

Azra (1999) mengungkapkan dalam sistem pendidikan 24 jam, interaksi antara Kyai, para ustadz, dan santri berjalan sangat intens. Interaksi dalam pendidikan tersebut dibangun atas fondasi budaya pesantren dan akhlakul karimah yang kuat. Hari-hari santri adalah hari-hari berinteraksi dengan teman sebayanya juga Kyai dan para ustadz. Rutinitas kegiatan dari pagi hari hingga malam sampai ketemu pagi lagi, mereka menghadapi makhluk hidup yang sama, orang yang sama, lingkungan yang sama, dinamika dan romantika yang sama pula. 
2) Penyelenggaraan Pendidikan Akhlak di Pesantren Cipari

Lickona (1997, hlm. 162) mengungkapkan bahwa pendidikan karakter mencakup tiga unsur pokok, yaitu mengetahui kebaikan (knowing the good), mencintai kebaikan (desiring the good), dan melakukan kebaikan (doing the good). Maka pendidikan karakter yang baik harus melibatkan bukan saja aspek pengetahuan yang baik (moral knowing), akan tetapi juga merasakan dengan baik (moral feeling), dan akhirnya menjadi perilaku yang baik (moral action). Namun agarmoral knowing, moral training, serta moral behaving peserta didik terbangun dengan utuh, diperlukan keteladanan guru untuk mengaplikasikan nilai tersebut dalam kehidupan sekolah (Hakam, 2015)

Dalam sudut pandang Islam menurut Ahmed (1970) pendidikan karakter atau pendidikan akhlak harus dikembangkan secara bertahap. Pertama, dalam membentuk karakter dan akhlak peserta didik harus didasarkan pada pengetahuan (knowing), yakni untuk mengetahui mana yang benar dan mana yang salah salah agar dapat bertanggung jawab baik sebagai individu (fardhu 'ain) dan sebagai bagian dari masyarakat (fardhu kifayah). Kedua, mengidentifikasi tindakan korektif dan kebenaran yang dirasakan di balik tindakan. Ketiga, identifikasi pengetahuan dan pemahaman tentang tindakan yang dipilih dan mempertahankan pilihan tindakan tersebut ('azm). Akhirnya, tindakan tersebut harus menjadi perwujudan perilaku teladan ('amal sholeh).

Namun dalam penelitian ini, peneliti menemukan fakta di pesantren Cipari bahwa dalam proses penyelenggaraan pendidikan akhlak di pesantren Cipari sedikit berbeda dengan teori-teori tersebut. Dalam prosesnya, pendidikan akhlak di pesantren Cipari mencakup 4 (empat) unsur utama yang saling mendukung satu sama lain yaitu, uswatun hasanah (keteladanan), latihan dan pembiasaan, pengamalan, serta pengajian kitab kuning dan mauidzhotul hasanah (nasihat yang baik).

\section{a) Uswatun Hasanah (Keteladanan)}

Dalam penelitian ini terungkap bahwa langkah pertama dalam mendidik dan membina akhlak para santri di pesantren Cipari adalah menggunakan metode uswatun hasanah (keteladanan), di mana metode uswatun hasanah (keteladanan) dari seorang Kyai dan juga gurunya merupakan kekuatan utama dalam pendidikan akhlak di pesantren Cipari, uswah dari Kyai dan para ustadz akan menjadi contoh utama yang akan selalu ditiru oleh para santrinya baik itu ucapan, perbuatan sehari-hari, sampai dalam tata cara ibadah. Begitu pun dalam pelaksanaan pendidikan akhlak santri di pesantren, mulai dari kegiatan pembelajaran, pelatihan dan pembiasaan nilai-nilai kebaikan, hingga dalam pengamalan sehari-hari santri, keteladanan dari Kyai dan para ustadz akan selalu ada dalam setiap proses dan tahapan pendidikan yang ada. 
Keteladanan dari warga pesantren (Kyai, keluarga Kyai, para ustadz, staf dan seluruh yang bekerja di pesantren) akan menjadi contoh yang akan selalu ditiru oleh para santrinya baik itu ucapan, perbuatan sehari-hari, sampai dalam tata cara ibadah. Metode keteladanan mewarnai semua proses penyelenggaraan pendidikan karakter di pesantren Cipari, teladan dari Kyai dan para ustadz akan selalu ada di dalam setiap rutinitas dan kegiatan di pesantren. Hal tersebut sesuai dengan pendapat (Hakam, 2015, hlm. 10) bahwa agar setiap tahapan pendidikan karakter mulai dari Moral Knowing, Moral Training, serta Moral Behaving peserta didik terbangun, diperlukan keteladanan guru untuk mengaplikasikan nilai tersebut dalam kehidupan sekolah.

Senada dengan pendapat tersebut, Lickona (1997) mengungkapkan bahwa untuk mengembangkan karakter peserta didik yang bersumber dari nilai-nilai spiritual dan ajaran agama, maka sekolah membutuhkan pendekatan yang komprehensif yang berusaha mengembangkan karakter melalui nilai-nilai moral yang menyeluruh dan konteks kehidupan spiritual sekolah, salah satu komponen yang paling penting menurut Lickona adalah bagaimana guru harus bertindak sebagai pengasuh, model, dan mentor moral bagi peserta didiknya.

Rasululloh SAW seperti yang dikemukakan (Hakam, 2015, hlm. 10) memberikan contoh dalam proses pembinaan akhlak manusia bahwa keteladanan (modeling) merupakan salah satu aspek yang paling penting, di mana pada tahap awal siapa pun harus belajar moral dan karakter melalui percontohan, dan dalam mencontoh diperlukan figur yang patut dicontoh, guru dituntut untuk menjadi panutan dan pribadi yang menampilkan nilai-nilai moral. Hal tersebut sesuai dengan temuan penelitian bahwa setiap kali Kyai dan para ustadz selesai mengajar kitab kuning, langsung dibarengi dengan diberikan contoh oleh Kyai dan para ustadznya, untuk kemudian diikuti dan dilaksanakan oleh para santri.

Azami (2016) menyatakan bahwa figur seorang Kyai dijadikan rujukan karena didasarkan pada pengalaman berharganya yang bisa dijadikan sebagai teladan dan sumber rujukan perilaku santrinya. Tindakan dari seorang Kyai biasanya dapat diterima oleh para santri tanpa harus bertanyatanya tentang hukum tindakan itu. Santri-santri menjadikan figur Kyai sebagai sumber rujukan perilaku mereka.

Kemasyhuran, perkembangan dan kelangsungan suatu pesantren banyak bergantung pada keahlian dan kedalaman ilmu, kharismatik, wibawa dan keterampilan Kyai yang bersangkutan dalam mengelola pesantrennya (Hasbullah, 1996). Kyai sebagai pengasuh pondok pesantren diposisikan sebagai top leader yang menjadi panutan bagi santrinya. Oleh karena itu, segala bentuk kebijakan pesantren berada di tangan Kyai, khususnya yang berkaitan dengan pelaksanaan pendidikan karakter di pesantren.

Kyai dan para ustadz tentu memiliki standar kualitas pribadi yang 
baik, mencangkup tanggung jawab, wibawa, mandiri dan disiplin (Mulyasa, 2008, hlm. 37). Selain itu Kyai dan para ustadz juga berperan sebagai orang tua santri ketika di pesantren. Semua perilaku Kyai dan ustadz yang baik maupun buruk akan dicontoh oleh santrinya. santri lebih banyak menilai apa yang Kyai dan para ustadz lakukan dalam pergaulan di pesantren dan di masyarakat dari pada apa yang ustadz katakan. Sehingga apa yang disampaikan oleh Kyai dan para ustadz harus pula dipraktekkan dalam kehidupan seharihari (Djamarah, 2005, hlm. 31). Hal itulah yang menjadikan ustadz memiliki peranan penting dalam pelaksanaan pendidikan akhlak di pesantren.

\section{b) Latihan dan Pembiasaan}

Langkah selanjutnya dari proses pendidikan akhlak di pesantren Cipari adalah melalui manhaj (metode) latihan dan pembiasaan, metode tersebut untuk melatih dan membiasakan santri mempraktekkan pemahaman mengenai akhlak yang baik serta nilai-nilai kebaikan yang telah diajarkan dalam kehidupan santri sehari-hari, hal ini dilakukan untuk mengembangkan menyentuh aspek hati nurani dan kepekaan santri terhadap nilai-nilai kebaikan itu sendiri. Hal tersebut sesuai dengan pendapat Ningsih (2015, hlm. 20) yang menjelaskan bahwa perasaanperasaan tentang diri, orang lain, dan kebaikan itu sendiri berkombinasi dengan pengetahuan moral untuk membentuk sumber dari motivasi moral seseorang, hal ini akan membantu individu atau dalam hal ini peserta didik dari hanya sekedar tahu menjadi melakukan tindakan moral.

Menurut Lickona (2012, hlm. 53) ada enam komponen yang harus terbentuk dalam melatih kepekaan moral seseorang, di antaranya sebagai berikut:

a. Kesadaran; Kesadaran mempunyai dua sisi: sisi kognitif (mengetahui mana yang benar) dan sisi emosional (merasa berkewajiban untuk melakukan hal yang benar). Banyak orang mengetahui mana yang benar tetapi sedikit yang merasa berkewajiban untuk melakukannya.

b. Menghargai diri sendiri; Jika seseorang memiliki acuan standar dalam menghargai diri sendiri, maka sebenarnya ia sedang menilai dirinya sendiri.

c. Empati; Empati berarti turut merasakan pengalaman atau keadaan orang lain.

d. Mencintai kebaikan; Orang yang baik tidak hanya belajar untuk membedakan kebaikan dan kejahatan tetapi juga untuk mencintai yang satu dan membenci yang lainnya.

e. Pengendalian diri sendiri; Emosi dapat mengalahkan akal sehat, penting untuk mengendalikan sikap memuaskan diri.

f. Kerendahan hati; Kerendahan hati merupakan sisi afektif dari pengetahuan pribadi. Keduaduanya benar-benar terbuka terhadap kebenaran dan kesediaan untuk memperbaiki kegagalan. Kerendahan hati juga membantu seseorang untuk mengatasi kesombongan. 
Keenam komponen tersebut dapat tertanam dalam diri peserta didik apabila peserta didik dilatih (training) untuk mempraktekkan segala hal baik dalam kehidupannya. Pendidikan Karakter bukan hanya sekedar mengajarkan nilai-nilai luhur yang diyakini masyarakat dan bangsa (moral knowing), tetapi juga melatih peserta didik untuk mengaplikasikan nilai-nilai luhur tersebut (moral training) (Hakam, 2015).

Kegiatan pembiasaan yang diharuskan dan dilakukan secara terus menerus dan berulang-ulang oleh para santri diharapkan akan membuat santri yang awalnya belum terbiasa karena masih membawa kebiasaan di lingkungan sebelumnya, menjadi terbiasa untuk melakukan berbagai kegiatan yang diwajibkan di pesantren Cipari. Hal tersebut senada dengan pendapat Aini (2017, hlm. 3) bahwa metode pembiasaan adalah cara yang digunakan oleh pendidik kepada peserta didik dalam proses belajar mengajar, dengan melakukan suatu perbuatan atau keterampilan tertentu secara terus menerus dan konsisten untuk waktu yang cukup lama, sehingga perbuatan atau keterampilan itu benar-benar dikuasai dan akhirnya menjadi suatu kebiasaan yang sulit ditinggalkan.

Karakter adalah gabungan dari kebiasaan-kebiasaan manusia. Kebiasaan adalah perilaku yang dilakukan tanpa harus berpikir terlebih dahulu, kebiasaan sulit berubah, tetapi bisa diubah dengan komitmen yang sungguh-sungguh (Covey, 2004). Kebiasaan (habits) yang baik adalah persinggungan antara pengetahuan (knowlegde), keahlian (skill) dan keinginan (desire). Pembiasaan merupakan sebuah metode dalam pendidikan berupa proses penanaman kebiasaan. Sementara yang dimaksud dengan kebiasaan itu sendiri adalah cara-cara bertindak yang persistent uniform dan hampir tidak diketahui oleh pelakunya (Iqbal, 2013, hlm. 246).

Sementara itu, Thorndike menyebutkan bahwa untuk memperoleh hasil yang baik maka kita memerlukan latihan. Latihan yang dimaksud ialah latihan yang dilakukan secara berulang-ulang dengan urutan yang benar dan secara teratur. Teori ini merujuk kepada sistem "cobacoba", yaitu suatu kegiatan yang bila kita gagal dalam melakukannya, maka kita harus terus mencoba hingga akhirnya berhasil (Choer, 2009).

Proses penyelenggaraan pendidikan karakter harus berjalan maksimal, Rasulullah SAW telah memberikan contoh pembinaan karakter akhlak manusia yang komprehensif, sebagaimana yang dikemukakan oleh (Hakam, 2015, hlm. 5-6), di antaranya:

a. Keteladanan, artinya pada tahap awal siapa pun harus belajar moral dan karakter melalui percontohan, di sekolah guru merupakan contoh bagi murid-muridnya.

b. Pembiasaan, artinya perilaku baik perlu dibiasakan, bukan merupakan pilihan, tetapi menjadi keharusan. Pembiasaan perbuatan baik harus terus menerus bukan situasional, untuk itulah diperlukan adanya suasana yang kondusif di sekolah dan keluarga agar nilai moral dapat 
teraplikasikan dalam setiap tindakannya.

c. Sosialisasi, yaitu menyampaikan nilai moral pada publik, baik melalui pengajaran, ceramah, khotbah, slogan, simbolisasi, berita, yang sifatnya selalu mengingatkan individu agar berbuat kebajikan.

d. Motivasi moral, yaitu menghadapkan individu atau kelompok pada sejumlah pilihan (baik perilaku maupun pertimbangan) yang sifatnya dilematis. Dilema moral seperti ini untuk mengokohkan prinsip moral yang telah ada pada diri individu, sehingga pada situasi apapun orang akan tetap konsisten berlaku bijak. Pribadi yang berprinsip inilah yang diupayakan melalui Pendidikan Karakter, sehingga moralitas dan akhlakul karimah akan menjadi watak seseorang.

Pembiasaan menjadi kunci penting dalam pendidikan akhlak di pesantren Cipari. Hampir seluruh kegiatan di pesantren Cipari bertujuan untuk membiasakan santri mempraktekkan dan mengamalkan nilai-nilai kebaikan, agar nilai-nilai karakter dan akhlak tersebut menjadi kepribadian yang melekat utuh dalam diri santri. Dari seluruh kegiatan pembiasaan di pesantren Cipari peneliti menemukan beberapa di antaranya sebagai berikut:

1) Sikap menghormati dan memuliakan Kyai, para ustadz, dan orang yang lebih tua.

2) Mengikuti pengajian rutin.

3) Taat pada perintah Kyai dan para ustadz.
4) Sholat fardhu berjamaah tepat waktu di masjid.

5) Mencuci pakaian sendiri.

6) Berbicara yang sopan.

7) Hidup sederhana.

8) Menghafal al-Qur'an (muroja'ah).

Pesantren Cipari sudah melatih dan membiasakan para santri untuk melakukan hal-hal tersebut dari sejak awal masuk ke pesantren. Para santri akan belajar dari perlakuan yang dialaminya, serta belajar dari apa yang mereka alami sehari-hari di pesantren Cipari.

Guna memperkuat program latihan dan pembiasaan tersebut, pesantren Cipari juga menggunakan metode intervensi untuk melatih para santri mempraktekkan nilai-nilai kebaikan dalam kehidupannya sehari. Bentuk intervensi tersebut berupa penegakan aturan dan regulasi yang disebut dengan Nidzomul Ma'had (tata tertib pesantren) yang di dalamnya memuat aturan-aturan yang harus ditaati oleh para santri. Kemendiknas (2011) menjelaskan bahwa pelaksanaan pendidikan karakter itu sendiri berlangsung dalam dua bentuk sekaligus yaitu intervensi (perlakuan) dan habituasi (pembiasaan). Artinya bila satu intervensi dibuat pada satu lembaga maka proses habituasi berlangsung dalam ketiga lembaga itu, dalam keluarga, di sekolah, dan masyarakat. Proses ini berlangsung terus menerus dan terencana sehingga karakter baik menjadi identitas diri seseorang.

Pembentukan karakter sehingga menjadi identitas (kepribadian) dapat diibaratkan seperti geraknya roda 
gerigi. Artinya satu tindakan atau intervensi akan memberi efek kepada objek, jika dijalankan berupa pembiasaan. Pembiasaan akan menjadi reward atau feedback bagi proses tindakan, secara terus menerus akan berjalan seperti roda gerigi yang saling menggerakkan sehingga menjadi identitas diri. Aplikasi praktis dari proses pendidikan karakter yang digambarkan di atas dapat dilaksanakan bila proses berjalan dalam manajemen dan pengawasan yang baik (Isnarmi, 2016, hlm. 366).

Berkowitz \& Bier (2005) menyimpulkan bahwa "effective character education is not adding a program or set of programs, rather it is a transformation of the culture and life of the school". Maksudnya, bahwa pendidikan karakter yang efektif bukan hanya tergantung dari banyaknya program yang dilakukan di sekolah, melainkan suatu transformasi budaya dan kehidupan baik di sekolah, keluarga dan lingkungan masyarakat peserta didik.

Budaya nilai moral dan akhlak di pesantren Cipari merupakan warisan nilai-nilai kebaikan dari para pendiri pesantren sejak awal pesantren didirikan, dan semua itu sudah terbentuk menjadi suatu budaya di pesantren Cipari yang masih terus dijaga sampai sekarang, yang kemudian nilai-nilai itu dipraktekkan dan dibiasakan kepada para santrinya. Hal tersebut senada dengan pendapat Hakam (2015, hlm. 8) bahwa untuk menciptakan seseorang yang berkarakter (moral being) itu bukan hanya terbatas pada penyampaian moral knowing dan moral training saja melainkan harus membiasakan anak untuk terus melakukan perbuatan baik, dan untuk menciptkan moral being perlu didukung kondisi dan lingkungan sekolah yang kondusif agar nilai-nilai kebaikan itu dapat teraplikasikan. Tugas seperti itu, menuntut sekolah untuk menjadi lembaga pembudayaan nilai moral, bukan hanya sebagai lembaga pengajaran moral dan lembaga pelatihan moral.

\section{c) Pengamalan}

Menurut Lickona (2012, hlm. 53) pengembangan aspek moral action (tindakan) atau moral behavior (tingkah laku) merupakan wujud nyata dari moral knowing dan moral feeling, terdiri dari tiga aspek yaitu:

1) Kecakapan moral; Kecakapan moral adalah kemampuan untuk mengubah penilaian dan perasaan moral ke dalam tindakan moral yang efektif.

2) Tekad/kemauan; Bertindak baik selalu menuntut tindakan nyata. Tekad adalah inti dari keberanian moral.

3) Kebiasaan; Sering kali seseorang tidak sadar akan pilihan yang benar. Mereka melakukan tindakan yang benar karena dorongan kebiasaan.

Metode pengamalan di pesantren Cipari ini merupakan sesuatu yang berkaitan erat dengan metode latihan dan pembiasaan sebelumnya, Islam adalah agama yang menuntut umatnya agar mengerjakan amal saleh yang di ridhoi Allah, menuntut manusia agar mengarahkan tingkah laku, naluri, dan kehidupan ini sehingga dapat mewujudkan perilaku dan akhlak yang 
baik. Agar perbuatan itu bisa berujung kepada amal saleh, maka dibutuhkan latihan dan pengalaman. Prinsip di pesantren Cipari mengenai ilmu yang bermanfaat adalah ilmu yang menghasilkan amal (ibadah), dan amal (ibadah) harus melahirkan akhlak yang baik.

Dalam temuan penelitian di pesantren Cipari, upaya yang dilakukan untuk mengembangkan aspek pengamalan para santri, yang pertama adalah melalui praktek ibadah. Melalui praktek ibadah tersebut pesantren Cipari meyakini banyak nilai-nilai kebaikan yang ada di dalam setiap praktek ibadah yang akan membentuk kepribadian santri menjadi lebih baik. Hal tersebut senada dengan pendapat dari Basher (1982) yang menyatakan bahwa ibadah adalah metode penting dalam mendidik karakter seorang muslim, melalui ritual-ritual ibadah dan tugastugas praktis Islam harus dimasukkan dalam proses mendidik individu untuk menjadi seseorang yang berkarakter dan berakhlak mulia (akhlakul karimah).

Kegiatan-kegiatan yang dijalani oleh para santri mendukung terwujudnya proses pendidikan yang dapat membentuk akhlak mulia para santri, di mana dalam kesehariannya mereka dituntut untuk hidup mandiri dalam berbagai hal. Mulai dari persoalan yang sederhana seperti mengatur keuangan yang dikirim orang tua agar cukup untuk sebulan, mencuci pakaian, sampai pada persoalan yang serius seperti belajar dan memahami pelajaran (Lanny, dkk. 2014)
Haidar (2005, hlm. 64) mengungkapkan bahwa pesantren adalah sistem pendidikan yang berlangsung sepanjang hari dari pagi hingga malam, sehingga santri diberikan jadwal kegiatan agar para santri tidak melakukan kegiatankegiatan yang tidak produktif yang dapat membuat santri melakukan perbuatan-perbuatan yang kurang baik.

Selain rutinitas kegiatan santri, dalam temuan penelitian terungkap bahwa pelaksanaan pendidikan akhlak dan penanaman nilai-nilai kebaikan di pesantren Cipari juga dilaksanakan dalam kegiatan ekstrakurikuler. Pesantren Cipari juga memiliki berbagai kegiatan ekstrakurikuler untuk para santri, baik kegiatan ekstrakurikuler di sekolah maupun di pesantren, kegiatan ekstrakurikuler juga merupakan salah satu metode dalam rangka pengembangan karakter dan penanaman nilai-nilai kebaikan bagi para santri di pesantren Cipari. Suryosubroto (2002, hlm. 271) mengungkapkan kegiatan ekstrakurikuler adalah kegiatan yang dilakukan di luar jam pelajaran tatap muka yang dilaksanakan di sekolah atau luar sekolah untuk memperkaya dan memperluas wawasan pengetahuan dan kemampuan yang telah dipelajari dari berbagai mata pelajaran dalam kurikulum. Sedangkan dalam konteks pesantren, maka kegiatan ekstrakurikuler dapat diartikan sebagai kegiatan belajar para santri di luar jam mengaji al-Qur'an dan kitab kuning. Menurut Hidayat dan Zayyinah (2014, hlm. 69) berpendapat bahwa tujuan penting 
kegiatan ekstrakurikuler ini adalah sebagai wahana pengembangan karakter santri. Hidayat dan Zayyinah (2014, hlm. 69) berpendapat bahwa kegiatan ekstrakurikuler dalam pondok pesantren memegang peran yang penting karena menjadi wahana dalam mengembangkan nilai-nilai karakter yang secara teori telah mereka dapatkan di bangku sekolah formal maupun kegiatan pengajaran kitab kuning dan mauidzotul hasanah dari Kyai dan para ustadz yang ada di dalam pondok pesantren.

Karakter yang baik terdiri atas mengetahui apa yang baik, menginginkan sesuatu yang baik dan melakukan hal yang baik. Kebiasaan dalam berpikir, kebiasaan nurani, kebiasaan dalam bertindak, ketigatiganya berperan penting dalam menuntun kehidupan yang bermoral, ketiganya mendukung kematangan moral seseorang (Hakam, 2015, hlm. 8).

\section{d) Pengajian Kitab Kuning dan Mauidzotul Hasanah}

Lickona (2012) menjelaskan bahwa langkah pertama dalam pelaksanaan pendidikan karakter di lembaga pendidikan adalah mengembangkan aspek pengetahuan (knowing) terlebih dahulu, hal tersebut dilakukan untuk memberikan pemahaman terhadap individu mengenai nilai-nilai kebaikan, mana yang boleh dilakukan dan tidak boleh dilakukan.

Temuan di pesantren Cipari menunjukan fakta yang berbeda dengan teori Lickona, karena di pesantren pengembangan aspek pengetahuan para santri tidak ditempatkan menjadi fokus utama yang disentuh dalam membina dan mendidik akhlak para santrinya. Meskipun tidak menjadi fokus utama pesantren, bukan berarti aspek pengetahuan (knowing) santri menjadi tidak penting, terbukti bahwa pesantren tetap menyentuh aspek tersebut melalui metode dan kegiatan pengajian kitab kuning dan mauidzhotul hasanah (nasihat yang baik). Pembelajaran dan pengkajian kitab kuning merupakan ciri khas pembelajaran di pesantren Salafiyah (tradisional), kitab kuning tidak hanya menjadi pusat orientasi dan pembelajaran, tetapi telah mendominasi studi keislaman pesantren dan mewarnai praktek keagamaan dalam berbagai dimensi kehidupan umat Islam, karena lengketnya dengan kitab kuning, kalangan pesantren mencoba bersikap, memaknai dan menjawab hampir seluruh persoalan yang muncul dan berkembang di masyarakat (Nasir, 2005, hlm. 25).

Selain menggunakan metode pengajaran kitab kuning, metode selanjutnya dalam rangka mengembangkan aspek pengetahuan santri mengenai pendidikan akhlak dan penanaman nilai-nilai kebaikan di pesantren Cipari adalah dengan menggunakan metode ceramah dan mauidzhotul hasanah (pemberian nasihat baik). Metode mauidzhotul hasanah tersebut merupakan salah satu pendekatan yang digunakan oleh Kyai di pesantren Cipari untuk menanamkan nilai-nilai kebaikan kepada para santri untuk kemudian mempraktekkan dan mengamalkannya secara bersama-sama. Hal tersebut 
senada dengan pendapat Rasyid Ridla (dalam Gunawan, 2014, hlm. 279) yang mengartikan maidzhotul hasanah adalah nasehat berupa peringatan atau kebaikan dan kebenaran dengan jalan apa yang dapat menyentuh hati dan membangkitkannya untuk beramal.

Hamid (1989, hlm. 260) menjelaskan bahwa mauidzhotul hasanah merupakan salah satu manhaj (metode) dalam dakwah untuk mengajak kejalan Allah dengan jalan memberi nasihat atau bimbingan dengan lemah lembut agar yang mendengarkan mau berbuat kebaikan.

Gunawan (2014, hlm. 279) menjelaskan terdapat 3 (tiga) unsur penting dalam metode ceramah dan mauidzhotul hasanah yang disampaikan Kyai dan para ustadz di pesantren, yaitu sebagai berikut:

1) Uraian tentang kebaikan dan kebenaran yang harus dilakukan oleh santri misalnya, tentang sopan santun, harus sholat berjamaah di masjid, dan semangat dalam menjalankan ibadah lainnya.

2) Motivasi dalam melakukan amal kebaikan sehari-hari.

3) Peringatan tentang dosa atau akibat yang akan didapat baik oleh diri santri sendiri maupun orang lain apabila santri berbuat sesuatu yang dilarang oleh Allah SWT.

Marzuki (2015, hlm 113) berpendapat bahwa para guru dan orang tua harus selalu memberikan nasihat-nasihat dan perhatian khusus kepada para siswa atau anak mereka dalam rangka pembinaan karakter. Cara ini sangat membantu dalam memotivasi siswa untuk memiliki komitmen dengan aturan-aturan atau nilai-nilai akhlak mulia yang harus diterapkan.

\section{SIMPULAN}

Penyelenggaraaan pendidikan karakter bagi pendidikan dasar khususnya pada jenjang sekolah dasar (SD/MI) dapat memperhatikan karakteristik dan mengadaptasi best practice pendidikan akhlak di pondok pesantren Cipari, yaitu: adanya Kyai, di sini kepala sekolah bertindak sebagai Kyai dan guru merupakan ustadz/ustadzah (murobbi), artinya selain mengajar juga memainkan peran sebagai uswatun hasanah (teladan) bagi peserta didiknya; memperlakukan peserta didik sebagai siswa sekaligus santri (Nyantri: mengabdi, berbakti, dan menjaga akhlak kesantriannya yang didapat dari guru), sehingga peserta didik memiliki kedekatan dan hubungan emosional dengan kepala sekolah dan guru-gurunya; adanya pengajian kitab kuning, berarti sekolah harus menjadi wahana peserta didik mendapatkan pengetahuan agama yang cukup, tempat membina dan mengembangkan akhlak peserta didik, juga sebagai tempat peserta didik berlatih mempraktekan nilai-nilai kebaikan yang bersumber dari ajaran agama Islam dalam hal ini; adanya tempat ibadah/Masjid, di mana sekolah memaksimalkan fungsi mesjid dan menjadikannya sebagai bagian yang tidak terpisahkan dari sebuah proses pembelajaran melalui kegiatan pembiasaan dan pengkondisian kepada peserta didiknya seperti sholat sunah dhuha berjamaah, sholat Dzuhur dan Ashar berjamaah, membaca dzikir 
setelah sholat, do'a bersama, pemberian ceramah dan mauidzotul hasanah (pemberian nasihat baik) setiap satu minggu sekali misalnya yang disampaikan oleh guru atau kepala sekolah atau sesekali mengundang Kyai atau ustadz dari luar, kegiatan dan pembiasaan tersebut untuk mendekatkan hati peserta didik dengan tempat ibadah; serta adanya pondok, maksudnya sekolah bukan membuat asrama melainkan sekolah menciptakan budaya akhlak dan suasana yang kondusif untuk menciptakan konteks atau suasana kehidupan yang mencerminkan nilainilai Islami ala pondok di pesantren.

Sehingga seluruh warga sekolah (kepala sekolah, guru, dan para staf) harus menciptakan suasana sekolah yang kondusif, memberikan keteladanan yang baik dalam kehidupan sehari-hari di sekolah, menciptakan budaya akhlak di sekolah baik dalam hubungan antar sesama guru maupun hubungan antara guru dan peserta didiknya, meningkatkan kerja sama dengan orang tua dengan melakukan pembinaan akhlak kepada orang tua baik melalui parents day, pengajian majelis ta'lim orang tua siswa yang diisi oleh guru di sekolah, hal tersebut untuk menyelaraskan visi misi dan tujuan sekolah dan orang tua yaitu sama-sama ingin mempunyai anak-anak yang berkarakter dan berakhlak mulia.

\section{DAFTAR RUJUKAN}

A. Steenbrink, K. (1994). Pesantren Madrasah Sekolah: Pendidikan Islam dalam Kurun Modern. Jakarta: LP3ES.

Abdullah, A. (2011). Pendidikan Islam Multikultural di Pesantren.
Yogyakarta: Pustaka Pelajar.

Ahmed, K. (1970). Some aspects of character building. Retrieved from

http://www.salaam.co.uk/knowle dge/aspects.php

Aini, V. N. (2017). Implementasi Pendidikan Karakter Melalui Metode Pembiasaan di Kelas 3 SD Negeri 2 Blunyahan. Retrieved from http://vidanooraini.blogs.uny.ac.i d/2017/10/23/

Azami, A. F. (2016). Pengembangan Aspek Nilai dalam Pendidikan Pesantren di PP Nurul Ummah. Jurnal Pemikiran Sosiologi. https://doi.org/10.22146/jps.v2i1. 23413

Azra, A. (1999). Pendidikan Islam: Tradisi dan Modernisasi Menuju Milenium Baru (Cetakan 1). Jakarta: Logos.

Basher, M. O. . (1982). Islamic Moral Education: An Introduction. Makkah: Ummul Quro University.

Berkowitz, M. W., \& Bier, M. C. (2005). What works in character education: A research-driven guide for educators. St. Louis, MO: $\quad$ Character Education Partnership. Retrieved July.

Choer, A. (2009). Psikolinguistik Kajian Teoretik. Jakarta: Rineka Cipta.

Cooley, A. (2008). Legislating Character: Moral Education in North Carolina's Public Schools. Educational Studies. https://doi.org/10.1080/00131940 802117563

Covey, S. R. (2004). The seven habits of highly effective poeple: powerful lesson in personal change. In The seven habits - an overview. https://doi.org/10.1002/pfi.41703 01009 
Dawam, R. (1995). Dunia Pesantren

Dalam Peta Pembaruan, dalam Pesantren dan Pembaruan. Jakarta: LP3ES.

Djamarah, S. B. (2005). Guru dan Anak Didik Dalam Interaksi Edukatif Suatu Pendekatan Teoritis Psikologis. Jakarta: Rineka Cipta.

Gunawan, H. (2014). Pendidikan Karakter Konsep dan Implikasi. Bandung: Alfabeta.

Haidar, M. A. (2005). Pesantren dari Transformasih Metodologi Menuju Demokratisasi Institusi. Jakarta: Erlangga.

Hakam, K. A. (2015). Pendidikan Karakter di Sekolah Dasar. Retrieved from https://kamaabdulhakam.wordpre ss.com/

Hamid, A. al-B. (1989). Fiqh alDakwah Fii Ingkar al-Mungkar. Kuwait: Dar al-Dakwah.

Hanafi, M. (2017). Membangun Profesionalisme Guru Dalam Bingkai Pendidikan Karakter. Jurnal Ilmu Budaya, 5(1), 35-45. Retrieved from https://journal.unhas.ac.id/index.p hp/jib/article/view/2356/1277

Hasbullah. (1996). Kapita Selekta Pendidikan Islam. Jakarta: PT. Raja Grafindo Persada.

Hidayat, K. (2008). Kyai Hamam Dja'far dan Pondok Pabelan:Kesaksian Santri, Kerabat, dan Sahabat. Jakarta: Dunia Pustaka Jaya.

Hidayat, N. (2016). Implementasi pendidikan karakter melalui pembiasaan di pondok pesantren pabelan. JURNAL JPSD (Jurnal Pendidikan Sekolah Dasar). https://doi.org/10.26555/jpsd.v2i 1.a4948

Iqbal, M. A. (2013). Konsep Pemikiran Al Ghazali Tentang Pendidikan. Jawa Timur.
Isnarmi, M. (2016). Pendekatan KritisTransformatif dalam PKn: Sebuah Upaya Pengembangan Karakter (Good Character). Jurnal Social Science, 1(1), 364378. Retrieved from http://repository.unp.ac.id/id/epri $\mathrm{nt} / 196$

Kafrawi. (1978). Pembaharuan Sistem Pendidikan Pondok Pesantren. Jakarta: Cemara Indah.

Kamin Sumardi. (2012). Potret Pendidikan Karakter Di Pondok Pesantren Salafiah. Jurnal Pendidikan Karak.

Kemendiknas. (2010). Pendidikan Karakter di Sekolah Menengah Pertama. Jakarta.

Kemendiknas. (2011a). Grand Design Revitalisasi Pendidikan Karakter di Sekolah Dasar Melalui Pendekatan Menyeluruh. Jakarta: Kemendiknas.

Kemendiknas. (2011b). Pedoman Pelaksanaan Pendidikan Karakter: Berdasarkan Pengalaman di satuan Pendidikan Rintisan. Jakarta, Indonesia.

Kurikulum, P. (2009). Kebijakan Nasional Pendidikan Karakter Bangsa. Jakarta: Puskur Litbang Kemendiknas.

Lanny, Oktavia., D. (2014). Pendidikan Karakter Berbasis Tradisi Pesantren. Jakarta: Rene Book.

Laoly, Y. H. (2017). Peraturan presiden republik indonesia nomor 87 tahun 2017 tentang penguatan pendidikan karakter. Peraturan Presiden Rapublik Indonesia.

Lickona, T. (1997). A Comprehensive Approach to Character Building in Catholic Schools. Journal of Catholic Education. https://doi.org/10.15365/joce.010 2051997 
Lickona, T. (2012). Educating For Character. Jakarta: PT. Bumi Aksara.

Mahmudah, D. (2008). Efektifitas Metode Dakwah Mauidzhotul Hasanah dalam Pembinaan Akhlak Santri At-Taqwa Putra Bekasi. Retrieved from http://repository.uinjkt.ac.id/dspa ce/bitstream/123456789/21299/1

Marzuki. (2015). Pendidikan Karakter Islam. Jakarta: Amzah.

Mastuhu. (1994). Dinamika Sistem Pendidikan Pesantren. Jakarta: INIS.

Moleong, L. J. (2009). Metodologi Penelitian Kualitatif. Bandung: PT Remaja Rosdakarya.

Nasir, R. (2005). Mencari Tipologi Format Pendidikan Ideal, Pondok Pesantren di Tengah Arus Perubahan. Yogyakarta: Pustaka Pelajar.

Ningsih, T. (2015). Implementasi Pendidikan Karakter (p. 20). p. 20. Purwokerto: STAIN Press.

Nofiaturrahmah, F. (2017). Metode pendidikan karakter di pesantren. Jurnal Pendidikan Agama Islam. https://doi.org/10.14421/jpai.201 4.112-04

Nuryaman. (2016). Mendikbud Pastikan 5 Hari Sekolah Mulai Tahun Ajaran 2017- 2018. Retrieved from http://www.pikiranrakyat.com/pendidikan/2016/11/1 $1 /$

Pradjarta, D. (1994). Memelihara Umat: Kiai Pesantren, Kiai Langgar di Jawa. Yogyakarta: LKiS.

Presiden Republik Indonesia. (2017). Peraturan Menteri Pendidikan dan Kebudayan RI Nomor 23, Tahun 2017, tentang Hari Sekolah.

Rahmadi, M. (2014). Pengelolaan pendidikan karakter berbasis islam. Jurnal Administrasi Pendidikan UPI.

Sistem Pendidikan Nasional. (2003). Undang-Undang No.20 Tahun 2003. Departemen Pendidikan Nasional.

Supriatna, M. (2017, July 20). Penguatan Pendidikan Karakter. Pikiranrakyat.Com, p. 26. Retrieved from pikiranrakyat.com

Suryosubroto. (2002). Proses Belajar Mengajar di Sekolah. Jakarta: Rineka Cipta.

Syafe'i, I. (2017). Pondok pesantren: Lembaga Pendidikan Pembentukan Karakter. AlTadzkiyyah: Jurnal Pendidikan Islam.

https://doi.org/10.24042/atjpi.v8i 1.2097

Yahya, S. (2016). Model Pendidikan Karakter di Pesantren: Studi Kasus di Pondok Modern AlSyaik Abdul Wahid Kota Baubau Sulawesi Tenggara. UIN Maulana Malik Ibrahim, Malang.

Zamakhsari, D. (2011). Tradisi Pesantren Studi Tentang Pandangan Hidup Kyai. Jakarta: LP3ES. 